\title{
The Handling Model for the Victims of Terrorism in Australia and Indonesia: A Comparative Study
}

\author{
Ali Masyhar $^{1 \mathrm{a}}$, Rodiyah ${ }^{2 \mathrm{~b}}$, Dani Muhtada ${ }^{3 \mathrm{c}}$ \\ ${ }^{1}$ Anti-Radicalism and Terrorism Studies Center, Faculty of Law, Universitas Negeri Semarang (UNNES), Indonesia \\ ${ }^{2}$ Department of Constitutional and Administrative Law, Faculty of Law, \\ Universitas Negeri Semarang (UNNES), Indonesia \\ aali_masyhar@mail.unnes.ac.id, ${ }^{\mathrm{b}}$ rodiyah@mail.unnes.ac.id, ${ }^{\mathrm{c}} \mathrm{dmuhtada@mail.unnes.ac.id}$
}

\begin{abstract}
The Bali Bombing of October 12, 2002 left a long-standing trauma for the victims as well as the families of the victims. Bali Bombing was really phenomenal, not only because it hit two objects at once, but also the number of the victims was quite fantastic - that is, 203 people. Although it has been a decade ago, but we can still feel the bitterness of the tragedy up to now. Although the tragedy occurred in Indonesia, the majority of the victims actually were the citizens of Australia. The number of the Australians becoming the victims reached 88, followed by Indonesians (38 people). Considering a large number of the victims, we need for a comparative study of the handling of the victims of terrorism that have been done by the Australian and Indonesian government. The objective of this research is to examine and to analyze the patterns and the ways the Australians and Indonesian handlings the victims of the Bali Bombing I, as well as reviewing and exploring the action/policy programs conducted by the governments for the victims as wells as the families of the victims. This research uses three ways of data collection, i.e. library/document study, interviews, and questionnaire. The data obtained were analyzed with legal hermeneutics before the conclusions are made.
\end{abstract}

Keywords—Bali Bombing; Victims of Terrorism; Handling Model

\section{INTRODUCTION}

Humans need a safe, orderly, prosperous, and peaceful life. No man wants misery. For that is the law is held. Laws exist to govern human life, regulate human interaction. The history of human life, which began with "homo homini lupus", is a mirror of barbaric life. The more civilized a nation, the more it promotes a mutual respect, respectfulness in pluralism. Therefore, if there is a person or group of persons who can not accept a pluralism, respect for the rights of others, impose their own will, it is a mirror of barbarity and deserves to be criticized for damaging the existing harmony. Damaging the order of harmony of human life is then called the crime.

Nowadays, the forms of crimes not only include conventional crimes such as theft, murder, robbery, rape and so on, but also the organized crimes, white collar crimes, top hat crimes, cyber crimes, corruptions, terrorism and the likes. These last models of crimes cannot be overcome only by conventional ordinary laws, as they are "extra ordinary crimes" which require extra ordinary measures.

The form of "extra ordinary crime" which has recently become the spotlight, not only for Indonesian governments, but also the governments all over the world, is terrorism. This is because terrorists are considered as "humanist hostis generis" - that is, the enemies of all mankinds.

The Indonesian government, for example, was shocked once the terrorist attack took place in Bali on
October 12, 2002. The government fog, reasonably enough because Indonesia does not have a law that regulates the eradication of terrorism. But now - since October 18, 2002 the enactment of Government Regulation in Lieu of Law No. 1 of 2002 on Combating Terrorism Crime (Perpu is confirmed to become Law through Law No. 15 of 2003, and for the next called the Terrorism Act) and supplemented by Perpu no. 2 Year 2002 on the Eradication of Terrorism Crime at the Bali Bombing Bombing Event October 12, 2002.

Bali bombing I was really phenomenal, not only because it hit two objects at once, but also the number of the victims was quite fantastic - that is, 203 people. This number of the victims became an international attention as it affected 22 countries. Australia became the country with the largest number of victims ( 88 people). Considering such a large number of the victims, we are interested in reviewing more about how the the governments handled the victims and the families of the victims.

To provide a boundary line in the discussion, we focus on two core issues:

a. What are the models for handling the victims and or the families of the Bali Bombing Victims in Indonesia and Australia?

b. What are the forms of policy for the victims and or the families of the victims taken by the governments of Australia and Indonesia?

The purpose of this study are:

a. To review and to analyze the patterns and methods of handling the Australian and Indonesian States 
for the victims and or the families of the victims of the Bali Bombing I.

b. To review and to explore the action/policy programs taken by the governments of Australia and Indonesia for the victims and or the families of the victims of the Bali Bombing I.

\section{RESEARCH METHOD}

This research used three methods of collecting data: library/document studies, interview, and questionnaire.

a. Library studies/documents.

This method is directed to obtain secondary data from primary, secondary, and non-legal materials. The tool used for document study is the document recording form (Faisal, 2005: 53).

b. Interview / interview

Interviews are a process of obtaining information for the purpose of research by means of question and answer while meeting face to face between the interviewer and the interviewee, either with or without using the guide (interview) (Bungin, 2001: 133). Kerlinger formulates the interview as a face to face situation when a person-interviewer asks someone questions designed to obtain answers relevant to a research problem (Kerlinger 1990: 770).

c. Questionnaire

Questionnaire used to explore the handling of victims and or the families of the victims of the terrorism crimes.

The proper method for understanding the meaning of the text is hermeneutics. Hermeneutics law is a method of interpretation of a text of law, rules of law, and the results of legal studies. Entering in it is an interpretation of one's meaning toward doctrine and worldview.

\section{RESULT AND DISCUSSION}

\section{A. The Handling of Bali Bombing Victims}

The term "Terrorism" began to be used in the late $18^{\text {th }}$ century and referred to the acts of violence committed by the government to ensure the adherence of its people. Even in France, after the French Revolution, the "Republik Terreur" was established under the leadership of Robespiere. The concept of terror, indeed beneficial to the perpetrators of state terrorism, because it holds power so that it can control the system of thoughts and feelings of the people (Masyhar, 2009: 44, Rapin, 2009: 165).

Categorically, Dr. Kent Leyne Oots defines "Terrorism" as (1) a military or psychological action designed to create fear, or to create economic or material destruction; (2) a method of coercing the behaviors of the others; (3) a criminal act of publicity; (4) criminal actions with political tendency; (5) politically motivated violence; and (6) a criminal action to achieve political or economic objectives (M. Riza Sihbudi, 1991: 94).

Referring to the definition of "terrorism", the act of economic destruction of a nation can be put into the category of an act of "Terrorism". For example, from mid-
1997 to the present, the Indonesian economy was shaken beginning with the fall of the Indonesian rupiahs against dollars, and the Indonesian government seemed to be helpless in dealing with the depletion of the foreign exchange.

The Bali Bombing in October $12^{\text {th }}, 2002$ did claim a lot of lives. The Bali bombings not only caused deaths, but also some serious injuries. It also left some other victims including the children, wives and families of the victims suffered from the tragedy.

The victims, as part of a criminal act today, has not yet received a full attention regarding their rights. As a matter of fact, the rights of the victims should be viewed as an integral part of the whole criminal justice system. So if we want to enforce the criminal law, it should include the protection for the victims from the criminal acts. So far, attention has been paid more to the offenders, not to the victims. Only the perpetrators of criminal acts became the center of the attention, including the attention to the process of the trial, the protection of their rights, as well as their punishments. Meanwhile, the victims seemed to get no much attention.

The position of the victims or the persons who have been harmed by such a crime seems to be very weak. The victim seems to be forgotten. The science of Criminal Law as well as the practice of criminal law only pays attention to the perpetrator, the person who commits a crime (Soedarto, 1977:191), or at best according to Barda Nawawi Arief (1998:47), it only protects the victims in abstracto (indirect protection) (Nawawi Arief, 1998:47). In more concrete terms, the compensation (as part of the victim's protection) has not been addressed in our current Criminal Code. If we want to look back at our history, in the era of Majapahit, there was a personal relationship between the victim and the perpetrator of the crime, in the sense that the victim could directly demand the retribution of what had been treated to him. However, the subsequent consequences could allow for reply. To avoid a wider effect, then the ruler took over the imposition of a criminal on behalf of the public interest. The execution of retaliation which was originally a civil nature changed its nature to something that concerns on the public interest. And the position of the victim was transformed into just an element of the legal order. A criminal act is then no longer a detriment to a person who is directly affected by the consequences but as something against the law that is contrary to something abstract called law order. In such cases, the victim becomes meaningless, he or she is abstracted.

According to United Nations Resolution No. 40/34, victims are individuals, individually or collectively, who suffer from the acts that violate applicable penal laws in a given country, including regulations that prohibit the abuse of power. The category of victims also includes persons who are the victims of acts that, although they are not a violation of applicable national criminal law, violate internationally recognized norms of human rights (Nawawi Arief, 1998:54).

The victim of an act is not only someone other than the perpetrator, but he or she can also the perpetrator him/herself (Soedarto, 1977: 45). Victims are obvious in the 
criminal offenses-criminal acts such as theft, fraud, murder and so forth. Yet, the victims become somewhat vague when they are in the criminal offenses whose losses are not immediately clear, such as in the case of environmental crimes. Moreover, the definition of the victim will be more blurred if the crime is in the form of adultery, abortus provocatus, the use of narcotics, and the likes. In addition to these concrete victims, there can also be abstract victims, such as the victims of the system of values, trust, truth (honesty), and the likes.

After discussing the victims theoretically, we will specifically discuss the handling of the victims of the Bali Bombing, particularly those who were left dead by the Bali Bombing explosion. On October $12^{\text {th }}$, people always commemorate the tragedy of Bali Bomb I. This commemoration automatically recalls the fates of the victims of such a barbaric event, not only the victims from Indonesia, but also from the other countries around the globe. Even, in such a commemoration, the Australian government flew victims' families from Australia to Bali and invited survivors and families of the victims of the bomb blast in Indonesia.

In Indonesia the fulfillment of rights and the country's attention is still perceived less. Even the Witness and Victim Protection Agency (LPSK) has repeatedly requested the attention from the Bali Provincial Government for the fulfillment of the economic, psychological, health and sustainability rights of the children of Bali bomb victims. Even though it has been fifteen years since the tragedy occurred, the heartbreaking incident still remains a problem for the survivors and the families who are left behind. In connection with economic access, Bali Bomb Victims have not been given any special access related to financial aids for the survival of the sons and daughters of Bali Bomb Victims (http://www.birohumas.baliprov.go.id/ Friday, November 24, 2017).

To sustain their survival, the victims eventually established "Isana Dewata", and abbreviation of "Isteri Suami dan Anak-Anak Korban Bom Pulau Dewata" (Wives, Husbands, and Children of the Bali Bombing Victims). Isana Dewata is a foundation that engaged in the gathering of the victims of the Bali Bombing I. They are united by the same fates as the victims of the Bali bombings. Primarily, they consist of widows whose husbands are victimized (died) in the Bali Bombing. Initially, they were ordinary housewives who did not even have any skills. Being forced to survive, in order to save the future of their children, they gathered in 2003, shortly after the tragedy of the Bali Bombing I, to make activities that allowed them to get income (economic value). At that time, they felt confused because they did not have any adequate skills. Luckily, one of them (it was only 5 widows who became the backbone of their young children) had a sewing skill. Thanks to the support of volunteers and donors, that primarily driven by Mr. David Wedd and his wife Moira. They were then assisted by sewing equipments, initial capitals, and even marketing process. They then made an association called Adopta (established in February 2003). Adopta was founded with the aims of (1) collecting fellow victims; (2) making a living; (3) sharing together.
For about two years, they were mentored and guided to be independent, until eventually they became totally independent in 2004/2005, including looking for market share for their (economic) activities. Finally they formed a foundation of Isana Dewata.

As strangers who had never met before, we found that they initially felt stiff to express their feelings to the researchers. Realizing this, the researchers finally changed the strategy by joining first in sewing sewing work activities they are working on. Over time the situation became liquid. This situation was ultimately used by the researchers to ask questions based on the unstructured interview method.

From the interviews, it was found that these widows were strong and tough women, who did not easily give up on the rush of economic crush after the pass of their husbands. They did not quite understand why their husbands had to become the victims. Their husbands were good people. Why did these good husbands have a shorter age than those who were evils. Those moments of anger, annoyance, resentment and even despair burst into the minds of these widows. However, they quickly realized that "the show must go on", life must go on. There is no point in lamenting too much for pain. Finally they were aware that all should return and surrender to the ultimate holder of the fate, God Almighty. The concept of destiny has been an efficacious tranquilizer for their resurrection. However, this does not mean then the perpetrators are just forgiven. They should be brought to justice and be accountable before the law.

Isana Dewata finally legalized in the form of foundation. The Isana Dewata Foundation has a vision to spread peace and to voice love to the whole society. The missions are:

a. to promote solidarity and familial strings among families of the victims of the Bali bombing, including widows, widowers, and children.

b. to help each others and exchange ideas.

c. to improve the education of children and the well-being of the families, both inward and inner to reach a better future.

d. to become a tool for disseminating peace, with their experience, to the whole society.

Starting from the same sense of destiny and feelings, they gathered some families of the Bali bomb victims. They met and exchanged stories about what they felt and experienced during the Bali Bombing incidents of October 12, 2002. They met and conducted activities together. Until eventually the entire families of Isana Dewata considered the need for this organization to be ratified in a more formal status. Accodingly, the Isana Dewata Foundation was established on September $27^{\text {th }}$, 2013 in Denpasar, Bali.

All members agreed to collect fees from each member to fund the cost of inauguration of the Isana Dewata Foundation. To achieve all agendas, the members of the Isana Dewata Foundation worked hands in hands with one another among the fellow members of the Foundation.

One of the activities conducted is the annual commemoration of the October 12 tragedy, which was always attended by all members of the Isana Dewata 
Foundation. As time passes and the entry of new members, the activities of the Isana Dewata Foundation become more colorful. Today, the membership of the Isana Dewata Foundation has reached 50 families, consisting of wifes, husbands and the children of the Bali Bombing victims, who live in in Bali, Java, Kalimantan and Jakarta.

\section{B. Policy Taken for Bali Bombing victims}

As has been explained in the previous section, the attention of the Indonesian government to the victims of the Bali Bomb I (especially for the survivors) has still not been maximized. Not only financial related issues, but there are also many untouched services (Ajeng Gandini WE, ICJR, October 12, 2017) Even today, many victims are still suffering, traumatized, and declining quality of their lifes after experiencing the Bali Bombing I. Based on the 2017 data from WPS and Victims Protection Agency (LPSK), the number of the victims of the Bali bombing I who are able to access medical, psychological and psychosocial support services from the government agencies are still limited. From 2016 to 2017, the number of victims who received medical assistance in LPSK was only 36 people. Of the 36 people, only 26 people are active recipients of the services in 2017, while the other 10 people have been inactive. Moreover, no compensation has been made for the the victims of Bali Bombing I. Although it has not been executed yet, the provision of compensation based on court decisions was once decided for victims of the Marriott Bombing and terrorist acts in Samarinda that occurred at the end of 2016 .

After the terrorist act of the Bali Bombing I in October $12^{\text {th }}$, 2012, the government of Indonesia issued Government Regulation in Lieu of Law (PERPPU) No. 1 of 2002 on the Eradication of the Criminal Act of Terrorism, which then subsequently ratified as Law No.. 15 of 2003 on the Stipulation of Perpu No. 1 of 2002 on the Eradication of Criminal Acts of Terrorism, into Law.

This Terrorism Act is a special and specific provision since it contains some new provisions which are not contained in existing legislation, and deviates from the general provisions as contained in the Criminal Code and Criminal Procedure Code. Among the special irregularities imposed by the Terrorism Act are the setting of legal subjects who are familiar with the corporation, special minimal arrangements and others.

Although it raised pros and cons among the public, the issuance of the Perpu can be a "repressive instrument of law" in dealing with the acts of terrorism in Indonesia. Unfortunately, despite the issuance of the law, there are still several acts of terror in Indonesia, including in Central Java. Thus, it still raised a question on the effectiveness of the law as it has not touched the causal factors of the terror.

As a matter of fact, Perpu No. 1 of 2002 has firmly regulated the compensation and restitution for the victims. Compensation becomes the responsibility of the state, whereas restitution become the responsibility of the perpetrators granted to the victims or their heirs. In the explanation of the Perpu, the compensation referred to the material and immaterial reimbursement. This is particularly different from the Criminal Procedure Code, which states that reimbursement of expenses incurred by the aggrieved party. Thus, it is limited to material nature of the compensation. This means that the provision on the compensation for the victims of terrorism is much better than the compensation for the victims of the other crimes. Unfortunately, the granting of the compensation and the restitution should be legally mentioned and be included at the same time in the verdicts of the judges. Moreover, the procedure is also a bot complicated as the victims or their proxies should submitted the request for compensation to the Minister of Finance, based on the verdict of the court that granted such a compensation. It would be much better if the state actively provided such compensation based on the court decision, not on the active request of the victims.

Australia, which has been known as a country with a good human rights reputation, also expressed panic by issuing numerous counterterrorism laws (Cherney, 2016), even Roach (2011) describing Australia's legal response as a form of hyper legislation. However, when it is compared with Indonesia, the Australian Government seems to have a pretty good guidance and attention to the victims of the 2002 Bali Bombing. After the Bali Bombing, the victims and their families are given trauma therapy. Although this trauma remedial therapy is not exclusive for the victims of the 2002 Bali Bombing and their families, as it is inclusive for all victims of crimes, this model can give the government's initial attention to the victims of the 2002 Bali Bombing and their families. This trauma is handled by psychologists who do have an expertise in the field of trauma recovery.

In regards to the economic aids and service access, the Australian Government is much better off than the Indonesian government. The Australian Government has provided some financial compensation to the victims and their families.

From the interviews, it was found that the quick response of the Australian government in dealing with traumatic recovery after the Bali bombing for the victims and their families shows that the Australian Government's attention to the victims is better than those given by the Indonesian government (Interview with Tony Machin, USQ, 9 April 2018).

Regarding the execution of the main perpetrators of the 2002 Bali Bombing and its effects on supporting traumatic healings for the victims and their families, it seemed that it did not significantly affect the betterment of the victims and their families in Australia. Particularly, Australia has firmly removed the death penalty for any kinds of criminal acts. Thus, the death penalty for the Bali bombers has no effect on the trauma healings of the Australian victims. This is because the trauma healing is directly related to a person's psychological condition.

\section{CONCLUSION}

From the above description, it can be concluded that the fulfillment of the rights and the concerns of the state are still perceived as lacking. The Government's responsibility in the fulfillment of the economic, psychological, health and sustainable rights of the families of the Bali bombing 
victims is quite minimal. Until now, these tragedy still leaves a problem for survivors and families who are left behind. The compensation and restitution that has been provided in legal instruments in Indonesia has not been implemented well in this case. So the victim has not felt the usefulness of the existence of such legal instruments. The policy taken by the Australian government against its citizens has been good enough to provide good guidance and attention to victims of the 2002 Bali Bomb theorem. After the Bali Bombing, the victims and their families are given trauma therapy.

\section{REFERENCES}

[1] Husaini, Adian, Jihad Osama Versus Amerika, Gema Insani Pers (Jakarta, 2001).

[2] Manullang, A.C, 2001, Menguak Tabu Intelijen : Teror, Motif dan Rezim, Panta Rhei, Jakarta.

[3] Akaha, Abduh Zulfidar (ed), Terorisme dan Konspirasi Anti Islam, Pustaka Al-Kautsar, (Jakarta, 2002).

[4] Hoefnagels, G. Peter, The Other Side Of Criminology, Kluwer-Deventer Holland (1969).

[5] Masyhar, Ali, Pergulatan Kebijakan Hukum Pidana dalam Ranah Tatanan Sosial, Unnes Press, (Semarang, 2008).

[6] ----------, Gaya Indonesia Menghadang Terorisme: Sebuah Kritik atas Kebijakan Hukum Pidana terhadap Tindak Pidana Terorisme, Mandar Maju (Bandung, 2009).

[7] Muladi, Demokratisasi, Hak Asasi Manusia, dan Reformasi Hukum di Indonesia, The Habibie Center, (Jakarta, 2002).

[8] Nawawi Arief, Barda, Beberapa Aspek Kebijakan Penegakan dan Pengembangan Hukum Pidana, Citra Aditya Bakti (Bandung, 1998).

[9] -------------, Penal Policy In The Prevention Of Increasing Sexual Cyber Crimes (Cyber Sex/Cyber Porn), Indonesian Law Journal, Vol. 2 No. 2, Desember 2007, ISSN: 1907-8463, National Law Departement Agency, Departement of law and Human Rights (2007).

[10] --------------------, Bunga Rampai Kebijakan Hukum Pidana (Perkembangan Penyusunan Konsep KUHP Baru), Kencana, (Jakarta, 2010)

[11] Sihbudi, M. Riza, Bara Timur Tengah, (Bandung, 1991).

[12] Sudarto, Kapita Selekta Hukum Pidana, Alumni, (Bandung, 1981).

[13] -------, Hukum dan Hukum Pidana, Alumni, (Bandung, 1981).

[14] Wignyosoebroto, Soetandyo, Hukum: Paradigma, Metode dan Masalah, Elsham dan HuMa, (Jakarta. 2002).

[15] Rapin, Ami-Jacques, Does Terrorism Create Terror?, Critical Studies on Terrorism, Vol. 2, No. 2, August 2009, 165-179 (2009).

[16] Roach, K. The 9/11 Eff ect: Comparative Counterterrorism. Cambridge: Cambridge University Press (2011).

[17] Cherney, Adrian and Kristina Murphy, What does it mean to be a moderate Muslim in the war on terror? Muslim interpretations and reactions, DOI: 10.1080/17539153.2015.1120105 (2016). 